[Vol. 104

\title{
NOTE
}

\section{FEDERAL TAXATION OF OIL PAYMENT TRANSACTIONS}

An infinite variety of oil interests can be created by contract. Those which entitle their owner to receive a fractional share of the proceeds of production ${ }^{1}$ from a stated oil reserve, not to exceed a specified amount, if, as and when oil is extracted are commonly called oil payments. ${ }^{2}$ Generally, the owner of an oil payment will share in the gross proceeds, free and clear of production costs, although some agreements may provide for a share of net income. ${ }^{3}$ Should the owner of the oil payment have, in addition to the right to share in the proceeds, a lien or personal covenant that the specified maximum amount would be paid, the relationship would be one of debtor-creditor and the oil payment would be merely the collateral security. The owner of an oil payment has no right to extract oil, and no dominion or control over the oil in place, ${ }^{4}$ but the agreement may contain the operator's personal covenant to drill for oil. ${ }^{5}$

An oil payment may be created by the owner of a royalty, ${ }^{8}$ working interest, ${ }^{7}$ or larger oil payment assigning to another the right to receive a stipulated portion of the proceeds accruing to the assignor's interest. Also, an owner of such an existing interest may, instead of carving an oil payment from his interest, reserve an oil payment for himself and transfer the balance of his interest to another. ${ }^{8}$

Both an oil payment and a royalty entitle their owner to a fractional portion of the proceeds of production. However, a royalty continues for the life of the oil reserve, ${ }^{9}$ whereas an oil payment is limited to its speci-

1. The proceeds can be payable in dollars or barrels of oil. Welsch, Tax Aspects of Ozoning and Disposing of Interests in Oil and Gas, 31 TAXES 855, 857 (1953).

2. See Kuntz, Assignments of Oil Payments, 31 TAxes 863, 864 (1953).

3. Walker, Oil Payments, 20 Texas L. REv. 259, 261 (1942).

4. See Tennant v. Dunn, 130 Tex. 285, 290, 110 S.W.2d 53, 56 (1937).

5. Lacking an express agreement, the courts may imply one. Walker, supra note 3 , at 287 .

6. A royalty is an interest in oil which entitles its holder to a share in the proceeds of the oil produced as long as there is production without, being charged with the cost of development or operation. The distinction between an "overriding royalty" and a "royalty" is that the former is created by reservation upon transfer by the lessee whereas the latter is reserved by the landowner upon the execution of a lease. Williams, Assignment of Leasehold, Royalty and Oil Payment, in SECOND ANNUAL INSTITUTF ON OII AND Gas LAW AND TAXation 469, 488-90 (1951).

7. A working interest is the label given the interest owned by the operator of the oil properties. Welsch, supra note 1 , at 855.

8. Kuntz, supra note 2 , at 864 .

9. Welsch, supra note 1 , at 857 . 
fied maximum amount. ${ }^{10}$ At the same time; an oil payment differs from a working interest, in addition to the former being a limited interest, in that the owner of the latter is the party who is actually extracting the oil.11

The specific legal attributes of an oil payment, aside from the right to receive stipulated proceeds from the production of oil, depend upon the characterization given oil transactions by state courts. ${ }^{12}$ In Texas, for example, all interests in oil are characterized as determinable fee interests in land.13 The "lease" between the landowner and the working interest is said to operate as a severance of the mineral estate from the fee and is therefore a conveyance of the oil in place.14 However, the owner of an oil payment, although having a present interest in real estate, does not have title to the oil in place. ${ }^{16}$ Still, the characterization as realty affects the legal incidents of an oil payment only in requiring that transfers conform to the statute governing conveyances of real estate ${ }^{18}$ and in subjecting the interest to an ad valorem tax. ${ }^{17}$ In most other states, the characterizations given oil payments and other interests in oil vary in numerous respects. ${ }^{18}$ Accordingly, the formalities to be observed in transferring an oil payment as well as the burden of state and local taxes will be determined by the appropriate transfer or tax statutes, if any, to which oil payments are held subject. However, the particular characterization given it in any state does not materially affect the oil payment's primary attribute as a right to receive income arising from the production of oil. ${ }^{18}$

Oil payments fulfill a valid and important need as a self-liquidating financing device ${ }^{20}$ as well as a means whereby the principals in this highly speculative industry may diffuse the risk among many investors. A lessee, or the transferee of a working interest or a royalty, can acquire his interest for a smaller cash outlay by permitting the lessor or transferor to reserve an oil payment. In addition, the holder of a working interest, by transferring an oil payment for cash, equipment, or services, can continue his operations with the consideration thereby received. Thus, limited capital will not cripple the entrepreneur and repayment can be accomplished through the natural functioning of the financed business.

10. Ibid.

11. Id. at 856 .

12. See discussion of the implications arising from such distinctions in Brown, Assignments of Interest in Oil and Gas Leases, Farm-Out Agreements, Bottom Hole Letters, Reservations of Overrides and Oil Payments, in FIFTH ANNUAL INSTITUTE on OII and Gas Law and Taxation 25 (1954).

13. Walker, supra note 3 , at $262-70$.

14. 1A Sunmorer, OIL AND GAs $\$ 165$ (2d ed. 1954); Brown, supra note 12, at 29.

15. Tennant v. Dunn, 130 Tex. 285, 290, 110 S.W.2d 53, 56 (1937).

16. Ibid.

17. O'Connor v. Quintana Petroleum Co., 134 Tex. 179, 133 S.W.2d 112 (1939).

18. 1A Suncurers, OIL aND GAs \$152 (2d ed. 1954).

19. For a complete discussion of the legal incidents arising from ownership of an oil payment, see Walker, supra note 3 , at 259 .

20. Walker, supra note 3; Welsch, Acquiring Properties Through Oil Payments and Related Methods, 32 TAXes 494 (1954). 
Moreover, this permits holders of all oil interests to anticipate their future income and yet retain their original investments. Such transactions resemble loans ${ }^{21}$ except that repayment is to be made from a specific source of income with no personal liability attaching, and since the ownercreditor thereby assumes a risk greater than exists in normal financing he is entitled to a greater return. An oil payment differs from most equity investments in that its duration is limited and the rights of the holder are more restricted. In recent years, the popularity of the oil payment as a financing device is being rivaled by its attraction as a means for avoiding the full impact of the income tax, as will be discussed herein.

In applying the provisions of the federal tax áct to legal relationships subject to varying characterizations under state law, "it is the will of Congress which controls, and the expression of its will in legislation, in the absence of language evidencing a different purpose, is to be interpreted so as to give a uniform application to a nationwide scheme of taxation." 22 Resort to state law may be had to determine the legal incidents of the interest in issue, but the federal statute determines when and how they shall be taxed. ${ }^{23}$ Inasmuch as the principal substantive right incident to ownership of an oil payment is that of receiving a portion of the proceeds from the production of oil, the owner of an oil payment should be taxed in the same manner as one who owns a right to receive future income. This Note will first consider the method of investment recovery which should be employed in determining the net taxable income from the proceeds of the oil payment. It will then deal with the special tax problems involving gifts and sales of oil payments.

\section{Recovery of Investment by OWner of Otl Payment}

The total gross proceeds paid the owner of an oil payment are includable in his gross income. ${ }^{24}$ Since the adoption of the sixteenth amendment, Congress has permitted deductions from gross income with the general objective of taxing only net income. ${ }^{25}$ The deductions allowed are for those expenses which normally are incurred for the production of income in a taxpayer's trade or business. In the case of certain expenditures which will ordinarily be of value in the taxpayer's business beyond the year incurred, the taxpayer will be permitted to deduct only that portion allocable to the taxable year in accordance with the provisions govern-

21. The court rejected the taxpayer's contention that an oil payment was a loan in Ortiz Oil Co. v. Commissioner, 102 F.2d 508 (5th Cir.), cert. denied, 308 U.S. 566 (1939). However, unlike the agreement in that case, some conveyances of oil payments stipulate an interest charge to be added. See the conveyances in P. G. Lake, Inc., 24 T.C. 1016 (1955) and Wm. Fleming, 24 T.C. 818 (1955).

22. Burnet v. Harmel, 287 U.S. 103, 110 (1932).

23. Ibid.

24. See T. W. Lee, 42 B.T.A. 1217 (1940), aff'd, 126 F.2d 825 (5th Cir. 1942).

25. Griswold, An Argument Against the Doctrine That Deductions Should Be Narrowly Construed as a Matter of Legislative Grace, 56 HARV. L. REv. 1142, 1144 (1943). 
ing the allowance for depreciation ${ }^{26}$ and depletion. ${ }^{27}$ Although both depreciation and depletion deductions embody the underlying tax policy of permitting a tax-free recovery of capital, ${ }^{28}$ a taxpayer who is entitled to depletion on income derived from oil may elect to deduct $27 \mathrm{x} / 2$ per cent of his gross income from the oil, regardless of how small his investment is, when the amount represented by that percentage exceeds the actual cost of his investment consumed. ${ }^{29}$ If he is entitled only to depreciation, he gets no such bonus deduction. Therefore it is essential to determine whether the owner of an oil payment is entitled to recover his investment by the allowance for depletion or whether he must be content to recover his cost through the depreciation deduction.

The diminution of a natural resource as a result of its extraction from the source of supply is known as depletion. ${ }^{30}$ Although the code does not exhaustively attempt to indicate those entitled to the allowance, it is inherent in the depletion concept that it be allowed to one having an investment in the mineral in place which is being consumed by the extraction of the mineral. Clearly, if there is but one person who owns the property and extracts the oil, that person is allowed the depletion deduction. ${ }^{31}$ Normally the ownership of oil producing property is divided among many persons with varying interests. The code provides specifcally that the depletion allowance shall be equitably apportioned between the lessor (owner of the fee) and the lessee (owner of the working interest)..$^{32}$ Beyond that provision, the code is silent.

\section{The Supreme Court and Depletion}

The Supreme Court has further clarified which of the other interests in oil may be allowed the depletion deduction, but the few decided cases still leave many questions. The Court has decided several cases in which a party, having had a fee or working interest which would clearly be entitled to the depletion allowance, reserved a royalty, oil payment or similar interest and transferred the balance of his original interest. ${ }^{33}$ In each case the issue posed was: did he sever his entire investment from the oil in place, or did he, by reserving some oil interest, retain an investment in oil in place which was recoverable through the depletion allowance. ${ }^{34}$ In the leading case of Palmer $v$. Bender, ${ }^{85}$ the Court held that the owner of a

26. INT. REv. CODE of 1954, $\$ 167$.

27. Id. §611. (1954).

28. 78 Cong. Rec. 6180 (1934); H.R. Rep. No. 1337, 83d Cong., 2d Sess. 22

29. INT. REV. CODE of 1954, §613.

30. 78 ConG. REC. 6180 (1934).

31. See Anderson v. Helvering, 310 U.S. 404, 408 (1940).

32. INT. REv. CoDE OF 1954, \$611.

33. E.g., Anderson v. Helvering, 310 U.S. 404 (1940); Thomas v. Perkins, 301 U.S. 655 (1937); Palmer v. Bender, 287 U.S. 551 (1933).

35. 287 U.S. 551 (1933). 
working interest, who reserved a royalty upon the assignment of his right to extract the oil, retained an interest in the oil identical to that of the lessor, and was thereby entitled to depletion. The Court indicated that whenever a taxpayer has acquired, by investment, an interest in the oil in place, and secures, by any form of legal relationship, income derived from its extraction upon which he is wholly dependent for a return of capital, he has an "economic interest" which entitles him to depletion. In Thomas v. Perkins, ${ }^{36}$ the Court found that when the assignor reserved an oil payment upon the sale of his working interest, the intention of the conveyance was to withhold an investment in sufficient oil in place to satisfy the oil payment. The assignor would therefore be permitted to recover his investment in the oil payment through the depletion allowance.

On the other hand, the Court has held that similar interests shall not be allowed a depletion deduction. A taxpayer was held to have sold his entire depletable interest where he transferred his oil payments, royalties and fee interests and reserved both an oil payment and a lien on the proceeds from a later sale of the fee, up to the amount of his oil payment. ${ }^{\text {at }}$ The Court concluded that he had severed his investment in the oil in place because he was not dependent solely on oil production for income. The Court also denied the depletion deduction to taxpayers who acquired a contractual right, not an oil payment, to share in the proceeds of a well if, as and when oil is produced. ${ }^{38}$ In one such case, the taxpayer was a processor of natural gas whose only investment was in a pipeline used to convey the gas to his plant; ${ }^{B 8}$ in another, the taxpayer was a stockholder who had traded his shares in a corporation which owned oil leases for a share of the net income from production of the leased wells. ${ }^{40}$ The Court reasoned that inasmuch as these taxpayers at no time owned or controlled the production of the oil, their investment was not in the oil in place and therefore they lacked an "economic interest" and possessed merely an "economic advantage," i.e., a right to share in the proceeds of production acquired by a contract with a party having a depletable interest. These decisions indicate that there must exist some relationship between the taxpayer's investment and the production of oil for there to be an investment in the "oil in place" so that the taxpayer may receive the depletion deduction. Exactly what this relationship must be remains unclear. ${ }^{41}$

36. 301 U.S. 655 (1937).

37. Anderson v. Helvering, 310 U.S. 404 (1940).

38. Helvering v. O'Donnell, 303 U.S. 370 (1938); Helvering v. Bankline Oil Co., 303 U.S. 362 (1938).

39. Ibid.

40. Helvering v. O'Donnell, 303 U.S. 370 (1938).

41. See Commissioner v. Southwest Exploration Co., 350 U.S. 308 (1956) where the necessary relationship was had by an upland owner who possessed the power to prevent extraction of the oil. The Court expressly declined to comment on whether "strangers 'disassociated from the lease' who may have contributed an essential facility to the drilling operation ..." would be entitled to the depletion allowance. Id. at 316 . 


\section{Depletion and Caried-Out Oil Payments}

As of this time, the Supreme Court has found an investment to be in the oil in place and has allowed the depletion deduction only where the taxpayers have the right to control the extraction of the oil, or, having had that right, leased it to another but continued to derive their income from the extraction of the oil to which they must look exclusively for a return of their capital.42 Cases coming to the lower federal courts have involved the question of depletion for oil interests, which the Supreme Court has not had occasion to review. In many of these cases the depletion deduction has been granted to taxpayers who at no time had the right to control the extraction of the oil. For example, in cases dealing with the right of the owner of a carved-out oil payment to claim the depletion allowance, the lower courts broadly interpreted Supreme Court dictum to permit a depletion deduction, ${ }^{43}$ reasoning that an investment in oil in place exists whenever a taxpayer's income is dependent solely on oil production. These courts have thus coalesced the two criteria of investment and dependency into one, and allowed depletion deductions for interests resembling those which the Supreme Court termed an "economic advantage" when denying the depletion deduction. Though such cases generally conclude that the taxpayer has an investment in "oil in place," they do not purport to explain how or why the investment was in the oil in place rather than in the contractual arrangement between the parties. The opinions apparently treat the depletion deduction as nothing more than an allocation method to provide for the tax-free return of capital in any case where the production of income varies directly with the production of oil. However, the concept of depletion implies that the party who has an investment in the wasting asset itself is the only one who is suffering depletion; all others who are dependent for their income upon production of the mineral can properly allocate and recover the cost of their investment over the productive life of their interest by taking a depreciation deduction. 44

The propriety of extending the depletion allowance to owners of all oil payments appears questionable. It is well settled that an oil payment owner who may also look to an alternative source for a return of his capital does not have the complete dependency required to qualify for the depletion deduction. ${ }^{45}$ For those who have the necessary dependency,

42. For a concise explanation of the Supreme Court's cases, see Commissioner v. Southwest Exploration Co., 350 U.S. 308 (1956).

43. E.g., Commissioner v. Rowan Drilling Co., 130 F.2d 62 (5th Cir. 1945); Lee v. Commissioner, 126 F.2d 825 (5th Cir. 1942); Ortiz Oil Co. v. Commissioner, 102 F.2d 508 (5th Cir.), cert. denied, 308 U.S. 566 (1939). Contra, Massey v. Commissioner, 143 F.2d 429 (5th Cir. 1944).

44. The depreciation provision appears to be broad enough to provide for such recovery. See INT. REv. CODE of 1954, \$ 167. See also O'Shaughnessy, Inc., P-H 1940 T.C. Mem. Dec. I 40261 , rev'd on finding of a depletable interest, 124 F.2d 33 (10th Cir. 1941); cf. Charles G. Barnes, 8 B.T.A. 360 (1927); Julia Andrews Bruce 5 B.T.A. 300 (1926).

45. Anderson v. Hẹlvering, 310 U.S. 404 (1940); see text at note 37 supra. 
there is the additional requirement that their investment must be in the "oil in place." This condition is met when the owner of an oil interest, who at one time had some sort of ownership or control over the oil and thus had an investment in the oil in place, reserves an oil payment upon the transfer of the balance of his interest. ${ }^{46}$ Since he must continue to look to the production of oil for a return of his investment, the owner of such reserved oil payments is entitled to the depletion allowance. When the oil payment is carved-out, however, the transferee of such an interest does not have the requisite control over the well, thereby rendering less certain the theoretical location of his investment. Resort to the definition of depletion is of little aid, since it speaks in conclusions of requiring an investment in the wasting asset. The words of the code being inconclusive, a proper approach would be one based upon congressional policy.

The percentage depletion provision was enacted to eliminate the administrative difficulty in determining the proper portion of the taxpayer's investment to be recovered during a taxable year. ${ }^{47}$ This provision also continued the increased deduction originally provided by the discovery depletion method, which was designed to result in an increased net after taxes and hence lessen the deterrent effect of a high tax burden on the development of oil resources in this highly speculative and vital industry. ${ }^{48}$ In general, there is no administrative problem in allocating the yearly investment consumed with an oil payment, since the investment and anticipated recovery are easily ascertained from the agreement of sale. Although it is possible that the anticipated recovery may be less than the face value of the payment and consequently some problems may arise, it is submitted that this would be less likely when an oil payment is carved-out after the well is producing than it would be at the development stage. In addition, should the owner of an oil payment which is created for purposes other than development of the oil property be denied percentage depletion, it would probably have no adverse effect on the production of oil.

Accordingly, where the consideration given for an oil payment is not restricted to the development of the oil property, there seems no reason to allow a depletion deduction to the owner of the oil payment. The investment in the oil remains in the transferor, the transferee having invested in a contractual arrangement whereby he has purchased a share of the proceeds of production of the oil. This investment, as any investment in an intangible having a fixed life, can be recovered through depreciation. ${ }^{4 \theta}$ On the other hand, some carved-out oil payments are exchanged for material, labor, or capital funds which are pledged to be employed exclusively in the development of the property from which the oil payment is carved. In these transactions, which are akin to joint ventures

46. See text at notes 33-36 supra.

47. See 90 Cong. Rec. 304 (1943).

48. See Baker \& Griswold, Percentage Depletion-A Correspondence, 64 Harv. L. REv. 361 passim (1951).

49. U.S. Treas. Reg. 118, $\$ 1.167$ (a)-3 (1956) ; see note 44 supra. 
involving the owners of the working interest and the oil payment, the owner of the oil payment has become so identified with the extraction of the mineral that recognizing his investment to be in the oil itself, and thereby entitling him to the depletion deduction, would not be inconsistent with the policy behind the percentage depletion provision.

In any case, percentage depletion will benefit the owner of an oil payment only if the basis of the oil payment is less than $27 \mathrm{r} / 2$ per cent of the expected pay-out. After a property has begun producing oil, it seems unlikely that an oil payment can be acquired for less than $27 \mathrm{x} / 2$ per cent of its face value. However, should this be the case, to stimulate their purchase so that the advantages gained by use of oil payments may continue to be obtained, the transferor may have to grant a larger oil payment for the consideration received if the transferee is denied a depletion deduction.

However, even if the lower federal courts are correct in permitting the owners of all "carved-out" oil payments to recover their investment by the depletion allowance, this does not of itself mean that an oil payment should be treated as anything other than a right to receive income where the issue is whether an oil payment is "property" or "income" in determining the tax consequences of a gift or sale.

\section{Gift of an Oil Payment}

Under our system of progressive taxation, if a taxpayer in a high tax bracket assigns part of his income to one in a lower bracket, the total tax paid by both will be less than it would be had the transfer not been made. Therefore, in some circumstances it would be advantageous taxwise for one to transfer income to close members of his family, to a trust created for his own or their benefit or, in some circumstances, to a charitable institution. ${ }^{50}$ In the case of gifts to a trust, the code provides that the settlor will be taxed for income arising therefrom where he is "benefited" thereby ${ }^{51}$ or he has, within ten years of the trust's creation, a reversionary interest ${ }^{52}$ or the power to control the beneficial enjoyment of the principal or income. $^{63}$ Although Congress has offered no guide as to other gifts, the courts have independently developed a doctrine, said to be implicit in the tax act, that where there is a gift of "income-producing property" the in-

50. For example, a taxpayer filing a separate return whose net taxable income would be $\$ 300,000$ would retain after taxes a net of $\$ 52,180$. If instead he had given a $\$ 50,000$ oil payment having a fair market value of $\$ 40,000$ to a charity, his net taxable income would not include the $\$ 50,000$ (see Lester A. Nordan, 22 T.C. 1132 (1954), nonacq., 1955-2 CuM. BuLL. 11) and he could claim a charitable deduction of $\$ 40,000$ reducing his net income to $\$ 210,000$. He would lose his depletion allowance on the $\$ 50,000$ in the amount of $\$ 13,750(271 / 2 \%)$, thereby making his net taxable income $\$ 223,750$. Since he actually received $\$ 250,000$, his net after taxes would be $\$ 71,567.50$, or $\$ 19,387.50$ greater. than it would be had he not been so charitable.

51. INT. REv. CODE OF 1954, \$677; see generally, id. $\$ \$ 671-78$. The consequence of these provisions is that the settlor, in order to avoid taxation for the trust income, must strip himself of every vestige of benefit, interest or control with regard to the trust property.

52. Id. $\$ 673$.

53. Id. $\$ 674$. 
come arising therefrom will be taxed to the donee, but where the gift is of the "income" alone it will be taxed to the donor. ${ }^{54}$ Where an oil payment is donated, does the application of this rule require the donor to pay the tax on its proceeds, or does the gift operate to shift the tax to the donee?

\section{Criteria for Taxing Assigned Income to the Donee}

This judicial doctrine, which requires one to pay a tax on income which he no longer has available for his own use, though seemingly harsh, was considered necessary to restrain tax avoidance schemes that may undermine an orderly tax program. Nevertheless, in determining the extent to which the doctrine should be applied, that objective must be balanced against the undesireability of restricting an individual's ability to deal freely with his own property. The basis for the rule was the Supreme Court's interpretation of the code as requiring the taxation of salary to the one earning it and of income from property to the owner of the property. ${ }^{65}$ However, the doctrinal simplicity masks the difficult problem of determining whether the "property" itself has been given away. Recognizing that the value of "income-producing property" is the present value of its anticipated future "income," the difference between the alternative conclusions is merely one of degree. This difference, however, is particularly significant where there is a gift of a fund entitling its owner to the income produced therefrom, such as the assignment by a trust beneficiary of a few years' income.

An analysis of the cases reveals that, in determining whether a gift is of "income" or "property," the courts have regularly employed criteria resembling those provided in the code for taxing the income of a trust to the grantor. ${ }^{56}$ These cases indicate that the donor will be taxed for income received by the donee in three instances. The first is when the donor has retained control over the production of the income. ${ }^{37}$ Inasmuch as the courts have concluded that the code requires one who earns or creates the right to receive income to bear the tax, this test merely identifies that person.

A second consideration is whether the donor has received any benefit from the assignment in the form of satisfaction of a legal obligation or such

54. See, e.g., Harrison v. Schaffner, 312 U.S. 579, 583-84 (1941) ; Lum v. Commissioner, 147 F.2d 356, 357 (3rd Cir. 1945), cf. Lucas v. Earl, 281 U..S. 111, 114-15 (1930).

55. See INT. REv. CoDE of 1954, $\$ 61$ (a) ; Helvering v. Horst, 311 U.S. 112, 120 (1940); Lucas v. Ear1, 281 U.S. 111, 114-15 (1930).

56: See text at notes 51-53 supra. The trust provisions were enacted to solve a problem similar to that involved with ordinary gifts of income, i.e., the tax avoidance potential inherent in the transaction. See H.R. REP. No. 179, 68th Cong., 1st Sess. 25 (1924).

57. See, e.g. Commissioner v. Sunnen, 333 U.S. 591 (1948) ; Burnet v. Leininger, 285 U.S. 136 (1932) ; Lucas v. Earl, 281 U.S. 111 (1930); McCulley Ashlock, 18 T.C. 405 (1952); cf. Lum v. Commissioner, 147 F.2d 356 (3rd Cir. 1945). 
gratification as is normally associated with expenditures of money. ${ }^{58}$ In cases where the donor has received such benefit, he may be taxed on the theory that the "enjoyment" experienced is the act by which the economic gain, which had accrued to him and is incident to the interest conveyed, is realized. ${ }^{69}$ This rationale overcomes the reluctance to tax unrealized income ${ }^{60}$ by concluding that enjoyment results in realization.

Finally, where the assignment is of an income-producing fund, the donor will be taxed for the income arising therefrom unless a substantial portion of his interest has been given away. ${ }^{61}$ Although it may be argued that the income is related to the ownership of property and therefore the donee is the proper party to bear the tax, the real problem is whether a short term assignment of an income-producing fund should be deemed a transfer of "property." In balancing the desire to safeguard the revenue against the unfairness of taxing the donor, it would seem that a reasonable criterion for determining taxability is the length of time during which the donee is to receive the income. A donor would be less likely to resort to the gift device to avoid high tax brackets where the income will be realized over a long period. One deterrent to a gift in such case is that the ultimate saving of taxes becomes less certain because of the increased possibility of intervening changes in the law or in the relative levels of the parties' tax brackets. Furthermore, it does not seem too unfair to treat a taxpayer as having received income if he deflects it immediately before it is received, since there is then a higher probability that the income will be used as he desires. On the other hand, where the income is deflected long before it is due, the possibility of subsequent modifications in economic conditions or in the relationship which existed between the donor and donee at the time of the gift suggests a lesser likelihood that the income, when actually received by the donee, will be used to fulfill the donor's wishes or be employed as if currently spent by the donor. For such long-term gifts, the motive of tax avoidance would be more remote than other considerations which are better left uninhibited by taxation and, consequently, the prophylactic rule adopted by the courts would be less necessary.

The courts have shifted the tax burden to the donee where he has acquired control over production of the income ${ }^{62}$ or has acquired a substantial portion of the interest conveyed. ${ }^{63}$ Since these circumstances are corollaries of the factors required for taxing the donor, their significance is obvious.

58. See, e.g., Helvering v. Eubank, 311 U.S. 122 (1940); Helvering v. Horst, 311 U.S. 112 (1940); Helvering v. Leonard, 310 U.S. 80 (1940); Helvering v. Fitch, 309 U.S. 149 (1940).

59. Helvering v. Horst, 311 U.S. 112, 118 (1940).

60 . If all income were taxed upon its accrual, giving it away would not avoid its taxation. Therefore, it is our reluctance to tax unrealized income that raises a problem in the case of gifts of income.

61. Compare Blair v. Commissioner, 300 U.S. 5 (1937), with Harrison v.

Schaffner, 312 U.S. 579 (1941) ; cf. Pearce v. Commissioner, 315 U.S. 543 (1942).

62. See Lum v. Commissioner, 147 F.2d 356 (3d Cir. 1945).

63. See Blair v. Commissioner, 300 U.S. 5 (1937). 


\section{Oil Payments Under the Income-Property Dichotomy}

Where the owner of an oil interest carves out and donates an oil payment, is the gift to be deemed one of "income" so that the proceeds will be taxed to the donor, or of "property" so that the tax burden will be shifted to the donee? Litigation of this issue has been involved in but two cases. In R. E. Naill, ${ }^{\text {s }}$ the taxpayer, owning a royalty, donated to a charitable trust a $\$ 300,000$ oil payment which was paid out in five months. The Board of Tax Appeals held that, since Texas law characterized the interest conveyed as a determinable fee or an estate for years in realty, the conveyence was of property and the income arising therefrom was not taxable to the assignor. This decision preceded the Supreme Court's full development of the income-property dichotomy and also the Court's explicit rejection of state characterizations of oil interests as controlling the application of the federal tax act. ${ }^{65}$ The Commissioner has since withdrawn his earlier acquiescence in the Nail decision, and his announced policy is to tax to the donor the income arising from a donated oil payment. ${ }^{66}$ However, in Lester A. Nordan, ${ }^{67}$ decided in 1954, the Tax Court followed R. E. Nail and held that the owner of a working interest was not to be taxed for the proceeds of a $\$ 115,000$ oil payment given by him to a church even though it had paid out within a year. Since the right to receive income acquired by the donee in each case was indentical, the decisions must be approached analytically in terms of the interest owned by the donor.

When the owner of a working interest, as in the Nordan case, carves out and donates an oil payment, his rights incident to the control of the well operations remain unchanged. The only effect of the transfer is that a share of the proceeds of production will be paid to the oil payment owner. The income paid to the oil payment owner is a direct consequence of the control and efforts expended by the owner of the working interest and is, in fact, a portion of what would otherwise have been the income of the working interest. This situation is analogous to those cases holding the donor's retention of control over income production sufficient to warrant his bearing the tax for the income produced in consequence of that control. ${ }^{68}$ The Nordan case thus appears incorrect, and the owner of the working interest should be taxed for the proceeds of an oil payment he has given away. ${ }^{69}$

64. 27 B.T.A. 33 (1932), acq., XII-1 CuM. Bull. 9 (1933), nonacq., 1949-1 Cum. Bull. 6.

65. Palmer v. Bender, 287 U.S. 551 (1933). 10.

66. See I.T. 3935, 1949-1 Cum. Bull. 39. See also I.T. 4007, 1950-1 Cum. Bull.

67. 22 T.C. 1132 (1954), nonacq., 1955-2 Cum. Burs. 11.

68. See Commissioner v. Sunnen, 333 U.S. 591 (1948); Burnet v. Leininger, 285 U.S. 136 (1932); Lucas v. Earl, 281 U.S. 111 (1930) ; McCulley Ashlock 18 T.C. 405 (1952) ; cf. Corliss v. Bowers, 281 U.S. 376 (1930); Lum v. Commissioner, 147 F.2d 356 (3d Cir. 1945).

69. See text and citations at notes 105-07 infra. 
The creation and gift of an oil payment by the owner of a royalty, as in the Nail case, presents a different problem since the owner of a royalty has no control over the extraction of oil or the production of income. Therefore, since the assigned interest was an income-producing "fund," the donor will be taxed for the proceeds of the donated oil payment unless it constituted a substantial property right. As has been suggested, the appropriate test for such a determination is the length of time over which the interest would pay out. ${ }^{70}$ Since the oil payment in the Nail case paid out in only five months, it seems that the interest should have been regarded as a transfer of the donor's income and taxed to him. ${ }^{71}$ Although it may be difficult for the court to set an absolute pay-out time requirement for determining taxability, the desirability of certainty in commercial and tax law calls for an effort to weigh against the tax avoidance possibilities the value of relieving a donor of $\operatorname{tax}$ on income he will not receive. The ten-year period provided to restrain tax avoidance by use of a short term trust presents a legislative standard enacted to solve a similar problem and is probably an adequate yardstick. ${ }^{72}$

In Commissioner v. Hawen, ${ }^{72 a}$ the Fifth Circuit applied the essence of the "substantial disposition" test and decided that an oil payment which had paid out in nineteen months was "income" rather than "property." Although the case involved the applicability of the capital gain provision to such interests, the decision was based on cases concerning determination of the proper taxpayer, and it therefore signifies a recognition by the courts of the relevance of the theory of those cases to the oil payment problem.

Where the owner of an oil payment carves out and gives a smaller oil payment, the issue should be resolved in the same manner as has been suggested for a gift made by the owner of a royalty. However, should the owner of an oil payment give away his entire interest, a conclusion that there was no substantial disposition of the donor's property seems inapplicable. Therefore, if the donor is to be taxed, it must be because the interest in toto was relatively so short-lived that it can be deemed a mere transfer of income. For example, if the anticipated life of the interest is no more than one year, even though it represents all of the donor's interest, the necessity of safeguarding the revenue would require that the donor be taxed. The only difference between the gift of the whole and the gift of part is that the evidence of tax avoidance as a motive is not so clear in the latter instance, since there may be no objective indication that the apparent altruistic purpose is limited. Nevertheless, it would seem that a similar rule is necessary to protect the revenue. However, since the sole

70. See text and citations at note 61 supra.

71. See text and citations at notes 105-07 infra.

72. See Hawaiian Trust Co., Ltd. v. Kanne, 172 F.2d 74 (9th Cir. 1949). See also Farkas v. Commissioner, 170 F.2d 201 (5th Cir. 1948); INT. REv. Cone of 1954, $\S \S 671-78$; U.S. Treas. Reg. 118, §39.22(a)-21 (1953).

72a. 231 F.2d 340 (5th Cir. 1956); see text and citations at notes 105-07 infra. 
justification for taxing the donor is to combat tax avoidance in this fashion, the donor's motive in making the gift is of significance in setting the outside limits of a prophylactic rule. Therefore, since the evidence of motive is equivocal where the donor has given all that he had and is unable to comply with a requirement of giving an interest with a longer life, it would seem equitable to reduce the time requirement to compensate for this limitation on the donor's ability to deal with his property.

\section{Treatment of Gains Realized on the Sale of an Oil Payment}

Where an oil payment is exchanged for material, labor, or money pledged for the development of the oil property, the transaction, akin to a joint venture, is not taxable since the consideration given by the transferee of the oil payment is, in effect, his capital contribution to the enterprise. ${ }^{73}$ However, where the assets conveyed are available for the personal use of the oil payment's tranferor, a gain realized on the sale or exchange of such property will be included in his gross income. ${ }^{74}$ A deduction is allowed from gross income for one-half of net long-term capital gains. ${ }^{75}$ Although an oil payment is merely a right to receive future income, it is a property right and a determination must be made whether it is of the class of property subject to capital gain treatment. ${ }^{76}$ It has been argued in the alternative that a net long-term gain realized on the sale of an oil payment should be taxed as a capital gain because it is either a capital asset ${ }^{77}$ or real property used in a trade or business. ${ }^{78}$

\section{The Capital Asset Provision and Rights to Future Income}

The code defines a capital asset as property held by a taxpayer, with certain enumerated exceptions. ${ }^{79}$ Although a right to share in future income is not per se one of the specified exceptions, an oil payment cannot be treated as a capital asset unless it comes within the meaning of "property" as used in the definition of a capital asset. "Property" can be interpreted broadly to include everything capable of being owned.80 However, the Supreme Court has recently indicated that a more restricted meaning was intended, saying:

"Congress intended that profits and losses arising from the everyday operation of a business be considered as ordinary income or loss

73. Statement by Rep. W. Mills in explanation of H.R. 9559, 84th Cong., 2d Sess., Feb. 28, 1956.

74. INT. REv. CoDE of 1954, §61(a) (3).

75. $I d . \S 1202$.

76. Id. $\S 1221-41$.

77. Id. $\$ 1221$.

78. $I d . \S 1231$.

79. Id. $\$ 1221$. The exceptions include property in the nature of inventory; real or depreciable property used in a trade or business; a copyright, literary, musical or artistic compositions held by certain taxpayers; accounts or notes receivable acquired in exchange for inventory; and non-interest bearing governmental obligations issued at a discount maturing in less than a year.

80. Biack, LAW Dictionary 1382 (4th ed. 1951). 
rather than capital gain or loss. The preferential treatment provided . - applies to transactions in property which are not the normal source of business income. . . . Since this section is an exception from the normal tax requirements of the Internal Revenue Code, the definition of a capital asset must be narrowly applied and its exclusions interpreted broadly. This is necessary to effectuate the basic congressional purpose. This Court has always construed narrowly the term 'capital assets'. . . ." 81

An examination of the legislative history of the capital gain provision indicates that the sale of an interest encompassing only a right to future income, such as an oil payment, was not envisaged as within its scope. ${ }^{82}$ Originally there was no special tax treatment for capital gains. ${ }^{83}$ However, owners of property held for purposes other than resale were then reluctant to sell, since a large portion of any appreciation in value would be lost through taxation at progressive rates. ${ }^{84}$ As a result, investment capital, instead of having the mobility desired by Congress, had become frozen, thereby limiting the supply of capital necessary for economic progress and depriving the treasury of any revenue from its accretion. ${ }^{85}$ Also it was believed that an equitable tax of gains realized over a period of years would approximate the tax that would have been paid at ordinary rates if the gain had been realized ratably over the period the property was held. ${ }^{86}$

These considerations are inapposite when applied to the sale of future income such as an oil payment. The sale of an oil payment, instead of realizing income derived from a capital accretion in prior periods, hastens the realization of future income. Especially in the case of relatively shortlived oil payments, the income is realized only a bit sooner than it would have been had the oil payment not been sold, so that the treasury would not have been deprived of revenue had the sale not occurred. In addition, the fiscal motives prompting the sale would still exist even though capital gain treatment is denied, inasmuch as the primary function of an oil payment in the industry is as a financing device. There exists an additional indication that Congress did not intend capital gain treatment for sales

81. Corn Products Refining Co. v. Commissioner, 350 U.S. 46, 52 (1955); cf. Hort v. Commissioner, 313 U.S. 28 (1941); Commissioner v. Bagley \& Sewall Co., 221 F.2d 944 (2d Cir. 1955), 104 U. PA. L. REV. 439.

82. For a discussion of the legislative history see Wells, Legislative History of Treatment of Capital Gains Under the Federal Income Tax, 1913-48, 2 NAT'L TAX. J. 12 (1949). See also, Miller, The "Capital Asset" Concept: A Critique of Capital Gains Tasation, 59 YAlE L.J. 837 (1950).

83. Wells, supra note 82 , at 12 .

84. H.R. Rep. No. 350, 67th Cong., 1st Sess. 10-11 (1921).

85. See S. Rer. No. 1567, 75th Cong., 3d Sess. 5-7 (1938); H.R. REP. No. 1860, 75th Cong., 3d Sess. 7 (1938); H.R. REP. No. 350, 67th Cong., 1st Sess. $10-11$ (1921).

86. Wells, supra note 82 , at 20; S. REP. No. 558, 73d Cong., 2d Sess. 11-12 (1934); Hearings Before the Subcommittee on Revision of Revenue Laws of the House Ways and Means Committee, 73d Cong., 2d Sess. 38-39 (1934); see note 84 supra. 
of carved-out oil payments. In 1946, a General Counsel Memorandum announced the Government's intention to tax such sales at ordinary rates. ${ }^{87}$ Although in 1950 the Senate Finance Committee proposed an amendment which would have reversed that stand and taxed such sales as capital gains, ${ }^{88}$ the conference committee eliminated this amendment. ${ }^{80}$

In cases involving sales of future income arising from interests other than oil payments, the courts have sometimes given ordinary income and in other instances capital gain treatment for the consideration received. These cases can be conveniently classified into three categories. The first involves the sale of future income which has been "earned" but not yet received by the party disposing of it. ${ }^{80}$ Typical of such cases is Helvering v. Smith, ${ }^{01}$ where the taxpayer was paid $\$ 125,000$ as consideration for his share of the fees accrued by the law partnership from which he was withdrawing. The court held the consideration taxable as ordinary income since the "commuted payment merely replaced the future income with cash." 92 Another class of cases involves the taxpayer's disposition of his entire interest consisting of a right to earnings from income-producing property.93 For example, in McAllister $v$. Commissioner, ${ }^{94}$ when the taxpayer sold her life estate in a trust, the court held the consideration received taxable as a capital gain. Such decisions follow the reasoning of Blair $v$. Commissioner ${ }^{95}$ that the transfer of a life estate in a trust is a transfer of trust property and not merely of income. A dissent in McAllister argued that the Blair holding, whereby the donor need not pay tax on the income of a donated life estate, did not compel capital gains treatment when a life estate was sold, and furthermore that such treatment was not in conformity with Congress' intent..$^{98}$ A third category of cases concerns the sale of a taxpayer's right to future income whose realization is contingent upon his own or someone else's efforts. ${ }^{97}$ Typical of this group are cases in which the taxpayer is paid a lump sum as consideration for a motion picture royalty

87. G.C.M. 24849, 1946-1 CuM. Bulz. 66.

88. S. REP. No. 2375, 81st Cong., 2d Sess. 66, 91 (1950).

89. H.R. REp. No. 3124, 81st Cong., 2d Sess. 28 (1950).

90. E.g., Trousdale v. Commissioner, 219 F.2d 563 (9th Cir. 1955); Fisher v. Commissioner, 209 F.2d 513 (6th Cir.), cert. denied, 347 U.S. 1014 (1954); Rhodes' Estate v. Commissioner, 131 F.2d 50 (6th Cir. 1942), affirming 43 B.T.A. 780 (1941); Helvering v. Smith, 90 F.2d 590 (2d Cir. 1937); F. Rodney Paine, 23 T.C. 391 (1954).

91. 90 F.2d 590 (2d Cir. 1937).

92. Id. at 592 .

93. E.g., Allen v. First Nat'l Bank \& Trust Co., 157 F.2d 592 (5th Cir. 1946), cert. denied, 330 U.S. 828 (1947); McAllister v. Commissioner, 157 F.2d 235 (2d Cir. 1946), cert. denied, 330 U.S. 826 (1947); Bell's Estate v. Commissioner, 137 F.2d 454 (8th Cir. 1943), reversing 46 B.T.A. 484 (1942).

94. 157 F.2d 235 (2d Cir. 1946), cert. denied, 330 U.S. 826 (1947).

95. 300 U.S. 5 (1937).

96. 157 F.2d at $237-41$.

97. E.g., F. W. Jessop, 16 T.C. 491 (1951); Herman Shumlin, 16 T.C. 407 (1951); George K. Gann, 41 B.T.A. 388 (1940); Goldsmith v. Commissioner, 143 F.2d 466 (2d Cir.) (concurring opinion), cert. denied, 323 U.S. 774 (1944); cf. General Artists Corp. v. Commissioner, 205 F.2d 360 (2d Cir. 1953). 
contract ${ }^{98}$ or for a release from his employment contract. ${ }^{98}$ The courts reason here that the cash payment, being in lieu of what would have been ordinary income, should be taxed as ordinary income.

\section{The Capital Asset Provision and Oil Payments}

There has recently been a great deal of litigation to test the propriety of capital gain treatment for gains realized on the sale and exchange of oil payments. Beginning with the case of John David Harem, ${ }^{100}$ the Tax Court has consistently held that a taxpayer who realizes a gain on the sale or exchange of a carved-out oil payment is entitled to the special tax treatment given capital gains. ${ }^{101}$ In the Hawn case, the court drew its authority from R. E. Nail and Lester A. Nordan, cases shown to be of questionable validity. ${ }^{102}$ Furthermore, the decision in the latter cases that a donated oil payment is "property" for purposes of determining the proper taxpayer, even if correct, does not compel the conclusion that an oil payment is "property" within the definition of a capital asset. The court in Haren also drew support from cases holding that oil payments are depletable interests. As has been shown, these cases merely establish that the owner of an oil payment has an investment which may be recovered tax free by using the depletion deduction; ${ }^{103}$ they do not require that an oil payment be considered a capital asset. Hawn, though doubtful in both reasoning and authority, established the precedent followed in the later Tax Court cases giving capital gains treatment to oil payment sales. ${ }^{104}$

The Fifth Circuit in Caldwell v. Campbell ${ }^{105}$ also permitted capital gains treatment, but in March 1956 that court, in Commissioner $v$. Hawn, ${ }^{106}$ reversed the Tax Court's decision in the Hazen case and for the first time treated the gain realized therein as ordinary income. Curiously enough, the decision was based on the theory of those cases dealing with ascertainment of the proper taxpayer where there is a gift of "income." Without mentioning Nail or Nordan, the court reasoned that there was no substantial disposition of the transferor's property, and hence the transfer was of "income" and the capital gain provision inapplicable. ${ }^{107}$ Ac-

98. E.g., Herman Shumlin, 16 T.C. 407 (1951) ; Goldsmith v. Commissioner, 143 F.2d 466 (2d Cir.) (concurring opinion), cert. denied, 323 U.S. 774 (1944). (1940).

99. E.g., F. W. Jessop, 16 T.C. 491 (1951); George K. Gann, 41 B.T.A. 388

100. 23 T.C. 516 (1954).

101. See Wm. Fleming, 24 T.C. 818 (1955); A. J. Slagter, Jr., 24 T.C. 935 (1955); P. G. Lake, Inc., 24 T.C. 1016 (1955); W. F. Weed, 24 T.C. 1025 (1955) (dealing with a sulphur payment); John Wrather, $14 \mathrm{CCH}$ Tax Ct. Mem. 345 (1955) ; R. B. Cowden, 14 CCH Tax Ct. Mem. 475 (1955).

102. See text at notes $64-72 a$ supra.

103. See p. 1095 supra.

104. See note 101 supra.

105. 218 F.2d 567 (5th Cir. 1955).

106. 231 F.2d 340 (5th Cir. 1956).

107. An inference may be drawn from the opinion in the instant case that the decisions in Nail and Nordan should also be decided on the basis of the time period 
cordingly, the Caldwell case was distinguished as involving a transfer of "property," since the anticipated pay-out of those oil payments was nine to thirteen years, whereas in Hawn it was paid out in nineteen months. The tests evolved to distinguish "income" from "property," when the problem is the proper party to pay the tax on donated income, are not necessarily appropriate in determining whether a sale of such interests results in ordinary income or a capital gain, since -different policy considerations apply to the respective situations. Whereas the object in the former is to balance the tax avoidance potential against the undesireability of restricting an individual's ability to deal freely with his property, the capital gain provision was designed to alleviate problems arising from the realization and taxation in a single tax year of capital appreciation accumulated during prior periods.

Without the benefit of the capital gain provision, a taxpayer who sells his right to future income may, because of our system of progressive taxation, pay a larger tax on the gain than he would had he not "bunched" his income by the sale. As a result, there would tend to be a reluctance to sell such interests, with the consequent unsatisfactory effects which the capital gain provision sought to rectify, such as loss in mobility of capital and the hardship of taxing income at rates higher than if it had been realized in the normal course of business. ${ }^{108}$ Although these considerations may be insignificant where the income sold would have been earned over a relatively short period of time, they raise serious problems when the interest sold is sizable and will be paid out over a lengthy period. Therefore, while there is no indication that Congress has specifically considered giving capital gains treatment to sales of future income, it appears that capital gain treatment should be available to gains realized upon the sale of sizeable long-term interests. Accordingly, the gist of the test applied in Commissioner v. Hazin, i.e., how substantial was the assigned interest, would appear proper. However, the courts, in determining the degree of substantiality necessary for the interest to be deemed "property," should be aware of the considerations applicable to the capital gain provision and not draw their yardstick indiscriminately from both gift and capital gains cases. In addition, it should be noted that except for the Hazen case, the analogy to the gift cases for determination of an interest as "property" has been confined principally to instances where the taxpayer, as in McAllister, sold his entire interest. 109

Analyzed in terms of the three categories of cases involving sales of future income, short-term carved-out oil payments should not receive capi-

dichotomy employed to determine whether there was a substantial disposition of the donor's property. Since the oil payments in both Nail and Nordan paid out in less time than that in Hazen, it is probable that the instant court would have reversed the decision in those cases and taxed the donor. See text at notes 64-69 supra.

108. See text and citations at notes $82-86$ supra.

109. See cases cited at note 93 supra; cf. Rhodes' Estate v. Commissioner, 131 F.2d 50 (6th Cir. 1942). 
tal gain treatment. When the owner of a working interest, royalty or oil payment carves out and sells an oil payment, the gain realized is a substitute for what would have been regarded as ordinary income to the transferor. Such transfers are analogous to sales of future income, the realization of which is contingent upon the transferor's or someone else's efforts, wherein the gain is taxed as ordinary income. ${ }^{110}$ This analogy is more striking where, as in $A . J$. Slagter, $J r_{.}{ }^{111}$ the owner of a working interest sold an oil payment to a refiner and agreed to give the buyer preference to buy oil from the wells owned by the working interest. In such a situation, were it not for the formalities of conveying an oil payment, it would be difficult to distinguish the transaction from an advance payment for the "inventory" of the transferor.

A more difficult question is encountered in a case like $R$. B. Coveden, ${ }^{112}$ where the owner of an oil payment, expected to pay-out in four years, sold his entire interest. Although the Supreme Court has never considered the problem, it is analogous to the sale of a trust life estate, which in $M c$ Allister and like cases has been accorded capital gain treatment by the lower courts. In such a case, as well as any other situation involving the sale of an oil payment with a long-term payout, it appears appropriate to resort to the rule that a disposition of a substantial portion of the vendor's interest will be deemed a sale of "property."

\section{Applicability of Section 1231 to Oil Payments}

In addition to capital assets, net long-term gains realized on the sale of real or depreciable property used in a trade or business are taxed as capital gains. ${ }^{113}$ The contention that the transfer of an oil payment is a conveyance of real property is based upon its characterization as an interest in real estate under Texas law. ${ }^{114}$ However, such characterization affects the legal incidents of an oil payment only for purposes of requiring conveyances to conform to the state law governing real estate, and subjecting it to an ad valorem tax.115 In applying federal tax provisions to interests subject to varying characterizations under state law, the code is to be interpreted so as to render uniform an application reflecting the will of Congress. ${ }^{116}$ Legislative history of the capital gains provision indicates that "real" property was meant to describe an interest greater than a mere right to receive income, even should the source of the income be real property. ${ }^{117}$ Also, since the reasons for the special treatment afforded such

110. See text at notes $97-99$ supra.

111. 24 T.C. 935 (1955).

112. 14 CCH Tax Ct. Mem. 475 (1955).

113. INT. REv. CODE OF 1954, \&1231.

114. See text at note 13 supra.

115. See text at notes $16-17$ supra.

116. Burnet v. Harmel, 287 U.S. 103, 110 (1932).

117. This provision was enacted to give relief to business men who disposed of their property at a loss due to depressed conditions. The real property provision was intended to treat "land" and depreciable property alike. See-S. REP. No. 1631, 77th Cong., 2d Sess. 50, 119 (1942). 
property are the same as prompted the capital asset provision, the real property provision appears equally inapplicable to assignments of short-term oil payments. An oil payment, therefore, should not be characterized as "real" property for the purpose of applying this provision. On the other hand, the provision applies equally to sales of depreciable property used in a taxpayer's trade or business. ${ }^{118}$ Although an oil payment owned by one having an "economic interest" is depletable, ${ }^{119}$ some carved-out oil payments when owned by a transferee are subject to the depreciation allowance..$^{120}$ In order for a gain realized on resale by the transferee to qualify for capital gain treatment, the transferee may not have held it primarily for sale to customers in the ordinary course of business. ${ }^{121}$ If the oil payment was held as an investment for the production of non-business income, the provision would be also inapplicable. ${ }^{122}$ In those few instances where the carved-out oil payment is "used in the taxpayer's trade or business," the courts would be justified in applying the statute literally, granting capital gain treatment, and leaving to Congress the task of equating the statutory language with the apparently contrary intention of the legislators.

Should the gain realized upon the sale of an oil payment be taxed as ordinary income, such sales will continue to be useful financing and tax devices. By realizing income in advance at the transferor's election, sales can be manipulated to level off the transferor's income brackets and also to avoid losing a portion of the percentage depletion allowance resulting from the $50 \%$ limitation. ${ }^{128}$

\section{Conclusions}

In construing the terms of the tax statute, the Supreme Court has many times looked to practicalities. ${ }^{124}$ By this approach, the Government's need for an orderly tax policy to produce revenues is balanced with the congressional policy, permeating the act, to treat the taxpayer equitably and not stymie the conduct of ordinary business transactions. These factors have therefore been considered herein, and the taxation of oil payments in accordance with the treatment given analogous interests would, as described, maintain an orderly tax policy without interfering with the usefulness of oil payments in the oil industry. Briefly, it appears that the present code provision should require oil payment transactions to be taxed as follows: (1) When a donated oil payment is given by the owner of the working interest, or when it will be paid out over a short period of time,

118. INT. Rev. Code of 1954, § 1231.

119. See, generally, text at notes 24-49 supra.

120. See text at note 49 supra.

121. INT. REv. Code of 1954, §1231(b) (1) (B).

122. Id. at $\$ 1231(\mathrm{~b})$.

123. $I d$. at $\$ 613(\mathrm{a})$.

124. See, e.g. Harrison v. Schaffner, 312 U.S. 579,582 (1941); Helvering v. Horst, 311 U.S. 112 (1940); Lucas v. Ear1, 281 UU S. 111 (1930). 
the donor should be taxed for the income arising therefrom. Only where the proceeds will be earned over a relatively long period of time should the incidence of the tax be shifted to the donee. (2) A similar dichotomy based on length of the pay-out period should be determinative as to taxing the gain realized on the sale of an oil payment as ordinary income or capital gain. (3) Where the proceeds of a donated oil payment are taxed to the donor, or the gain on the sale is taxed as ordinary income to the transferor, each should be entitled to recover his investment by the depletion allowance. (4) On the other hand, where the gift results in the donee's liability for the tax on the proceeds, the donee, as well as the purchaser where the oil payment is sold, should be limited to the depreciation allowance in recovering his investment.

In February 1956, H.R. 9559 was introduced and referred to the House Ways and Means Committee. ${ }^{225}$ This bill seeks to reverse the tax treatment generally accorded oil payments by the courts. However, its principal provisions are in accord with the results herein determined as required under present provisions. The major difference between the treatment proposed by the bill and that recommended here as appropriate under present code provisions is the bill's failure to recognize a short-long life dichotomy. The bill proposes that the gain on all oil payments be taxed as ordinary income, and that the proceeds of all donated oil payments be taxed to the donor with the exception of gifts to charitable institutions payable for a minimum of two years. The wisdom of virtually abolishing the time period dichotomy can be determined only by a value judgment as to the factors militating towards different treatment of long-term interests in each of the instances mentioned.

The recent case of Commissioner v. Harom, decided since introduction of the bill, may herald correction by the courts of the generally erratic treatment they have accorded oil payment transactions. However, even though results similar to those proposed by the bill can be achieved under the present code provisions, the general trend of the cases on the subject as well as the desirability of achieving certainty in this area of law indicate that legislative clarification is sorely needed.

125. 102 Cong. Rec. 2996 (daily ed. Feb. 27, 1956). 